\title{
Näkemyksiä ja neuvoja johtajan työstä
}

\section{Reijo Korhonen 1996. Tämä ihmisen johtaminen. Otava. Reijo Maunula 1996. Kirje esimiehelle. 2. täydennetty painos. Edita.}

Kun tulin ensimmäisen kerran esimiestehtävään sivistysorganisaatiossa, minua varoitettiin johtamistaidon kirjoista ja kursseista. Niitä pidettiin lähtökohdiltaan yksinkertaistavina ja ihanteellisina, ihmiskäsitykseltään mekanistisina. Sanottiin, että niiden opit uudistettiin hätäisesti joka toinen vuosi. Varoittajat tarkoittivat ilmeisesti, että vain Siperia opettaa.

Reijo Korhosen Johtamistaidon Opiston Aavarantasarjassa julkaisema kirja Tämä ihmisten johtaminen edustaa ilahduttavasti monipuolista ja kriittistä johtamisen kysymysten tarkastelua. Kirja vilisee kysymyksiä, vastauksia on vähän. Vastaukset olisivatkin parhaimmillaankin puolitotuuksia. Kysymyksistä ei synny kokonaiskuvaa, mutta ne antavat aineksia keskusteluun, monenlaisten kokonaiskuvien kehittelyyn.

Korhonen korostaa, että johtamisen kehittämisen tulee lähteä diagnoosista. Organisaatiot käyttävät paljon rahaa sen selvittämiseksi, miten asioiden tulisi olla, mutta eivät yleensä tiedä, miten ne ovat. Tulevaisuus on kiehtova, tämän päivän tilanne raadollinen ja triviaali. Ja edelleen: tilannekuvan hahmottaminen ei ole vain tiedon asia, tärkeitä ovat myös arvot, asenteet ja tunteet.

Kirjan monet kuvaukset työpaikkojen keskustelukyvyttömyydestä ovat uskottavia. Keskustelutilaisuudet ovat rohkeita varten. Ihmiset eivät uskalla sanoa, että he eivät uskalla sanoa. Kehottavan, velvoittavan ja painostavan kulttuurin työpaikalla ihmiset tuntevat, että heidän vaikutusmahdollisuutensa ovat olemattomat. Vallattomuus turmelee aina, ehdoton vallattomuus ehdottomasti, kuten Korhonen kirjoittaa.

Korhonen puhuu voimakkaasti valmennuksesta koulutuksen sijasta ja korostetaan henkilöstön tiedon ja ymmärryksen merkitystä. Jos ihmiset ymmärtävät, he myös tekevät. Vahvan todistuksen tästä antaa tutkimus amerikkalaisten siivoojien työn ohjauksesta. Kun siivooja voi tutustua toimistohuoneessa työskentelevään ihmiseen, hänen työhönsä ja siihen, mihin huonetta käytetään, hänen työnsä tarkoitus selkiytyy ja syvenee. Seurauksena on, että siivouksen kustannukset putoavat ja reklamaatiot vähenevät.

Vaikka henkilöstön tietämättömyys antaa johdolle valtaa ja henkilöstön ymmärryksen kasvu tekee monessa tapauksessa kipeää, suomalaiset johtajat pitävät johtamisen kehittämistä tarpeellisena. Tämä tulee ilmi selvityksestä, jossa sata johtajaa esittää näkemyksensä nykyisestä organisaatiostaan ja siitä, miten hierarkkinen organisaatio on ja miten hyvin sen tavoitteet ovat selvillä. Samaan nelikenttään he merkitsivät kuvitteellisen ihannetilan. Tuloksena oli, että johtajat haluaisivat työskennellä nykyistä matalammassa organisaatiossa, jossa henkilöstö tuntee yrityksen tavoitteet nykyistä selvästi paremmin.

Korhonen hahmottelee käytännön kokemusten ja tutkimusten pohjalta kunnianhimoisen näkemyksen uudesta johtajuudesta. Johtaja on tasapainoinen esimies, joka luo menestymismahdollisuuksia henkilöstölle eikä vain itselleen. Hän rohkaisee kokeilua, luottaa ihmisiin, tukee ja suvaitsee erilaisuutta, antaa vastuuta ja valtuuksia, innostaa uuteen, luo yhteisen näkemyksen, ottaa riskejä, sietää virheitä ja arvostelua, neuvoo ja ohjaa sekä etsii uusia ajatuksia. 
Mutta sitten Korhonen siteeraa antropologi Matti Sarmelaa:

"Tietoyhteiskunnan ekorakenteet tarvitsevat ihmislajin, joka henkisesti selviää totaalisella kilpailuareenalla tai sen ulkopuolella. Postlokaalisen ihmislajin on oltava puhtaaksi viljelty minä-ihminen, joka niin suorittajana kuin vastaanottajanakin peilaa koko olemassaolonsa itseensä. Maailman keskipiste on yksilö itse... Postlokaalinen ihminen on .... omille tarpeilleen elävä proteaaninen narsisti."

Narsistinen suuntaus on sovittamattomassa ristiriidassa sen kanssa, mitä Korhonen kirjoittaa tulevaisuuden hyvästä johtajasta. Onko kehittyneestä leaderistä ja visionääristä, joka antaa alaistensa kehittyä niin persoonallisuuksina kuin työntekijöinäkin, tulossa harvinaisuus jo ennen kuin olemme häntä yleisesti edes tavanneet?

Kaiken kaikkiaan Korhonen osaa asettaa tärkeitä kysymyksiä johtajille. Hän käyttää selkeää ja ymmärrettävää kieltä - siinäkin hän kelpaa esimerkiksi johtajalle.

\section{Tiimit ja johtaminen}

Reijo Maunulan Aavaranta-sarjassa julkaiseman kirjan Kirje esimiehelle ulkoasu yllättää kukka-aiheellaan. Ehkä Maunula haluaa viestiä, että kirja ei vältä pehmoiluksi monesti miellettäviä näkemyksiä - niin kuin ei vältäkään. Ehkä kukka on paikallaan senkin takia, että kirja ei ole ainoastaan erinomaisen luettava, vaan monin paikoin myös nautittava esimerkiksi mainiosti valittujen kirjallisuuden viittausten ja lainausten osalta.

Maunula käsittelee tiimejä ja tiimiytymistä tutkimusten ja kokemusten pohjalta nimenomaan käytännön esimiestyön tarpeita ajatellen. Tiimien monia arvokkaita vaikutuksia koskeneiden hehkutusten jälkeen on turvallista lukea, että tiimit ovat vaikeita asioita. Erityisesti luovan työn tekijät ovat epäilleet niitä.

Näin Maunula:

"Jos synergiaetuja haetaan jäsenten erilaisuutta hyödyntäen, kuitenkin yhteisten pelisääntöjen puitteissa toimien ja yhteiseltä arvopohjalta ponnistaen, ei esimiehen asema ja tehtävä liene helppo. Millainenhan tungos olisi sellaisen tiimin vetäjän paikalle, jossa jäseninä olisivat Hannu Taanila, Seppo Räty ja Paavo Väyrynen?"

Tutkimukset osoittavat, että tehokkuustavoitteet painottuvat tiimiytymispäätöksissä ihmisten kasvutavoitteiden kustannuksella. Tämän takia on syytä nostaa esimiehelle osoitetun kirjeen ohjeista kaksi kohtaa muiden edelle: anna meidän itse päättää ja luo oppimis- ja kehittymismahdollisuuksia.

Maunula käsittelee ansiokkaasti kysymystä sisäisestä yrittäjyydestä ja siihen liittyvistä johtamisen haasteista. Hän toteaa, että esimiehen tärkeä tehtävä on saada ne työyhteisön jäsenet, jotka ovat ulkokohtaisia katselijoita, innostumaan sisäiseen yrittäjyyteen. Oikein sovelletut kehityskeskustelut tulosjohtamisen osana ovat tässä tärkeä keino. Nykyaikaisen johtamistyön käytännön tarpeiden kannalta luku tulosjohtamisen kehityskeskusteluista on kirjan keskeisintä antia.

"Jos esimies tulosjohtamisen kehityskeskusteluissa antaa selkeät ohjeet, osoittaa tarkasti resurssit ja keinot, jotka keskustelukumppanilla on käytettävissään, määrittelee tiukasti seurantaan ja arviointiin käytettävät mittarit, niin alainen odottaa, että esimies antaa selkeät ohjeet, osoittaa tarkasti resurssit ja keinot, määrittelee tiukasti seurantaan ja arviointiin käytettävät mittarit. Ei enempää eikä vähempää."

Jos esimies kehityskeskustelussa toimii vain omilla ehdoillaan, alaiset kääpiöityvät itseään pienemmiksi, tunnetta osallistumisesta tai omanarvontunnosta ei ole. Sisäisen yrittäjyyden mahdollisuudet ovat vähäiset. Toisaalta esimies ei saa luopua omasta vastuustaan. Alaiset eivät ole aina oikeassa, eivät tunne 
kokonaisuutta, eivät näe omien tehtäviensä yli. Maunula neuvoo: hyvässä kehityskeskustelussa pyritään plussasummapeliin, jossa molemmat voittavat.

Kirjan toiseen painokseen on otettu uusi luku Asiantuntijatiimin odotuksia vetäjälle. Nämä tiimit on jaettu kahteen ryhmään: tiedon luomiseen, yhdistämiseen, välittämiseen ja jakeluun erikoistuneet sekä elämyksellisiä asiantuntijapalveluja tuottavat.

Asiantuntijatiimien vetäminen on erityisen vaativa työ. Omanarvontuntoiset ja yksilölliset asiantuntijat vieroksuvat sitouttamista ja hidasta kollektiivista päätöksentekoa. Asiantuntijat kokevat kokouksissa istumisen tuskallisena, elleivät voi itse niissä loistaa. Asiantuntijan itsetunnon ja ammattitaidon ylläpitämisen kannalta on tärkeää, että hänellä on suuri toimintavapaus, vaikka yhteisiä pelisääntöjä noudatetaankin.

Maunula esittää näidenkin tiimien osalta monia hyvin perusteltuja esimieheen kohdistuvia odotuksia. Asiantuntijatiimin odotusten huomioonottava johtaminen on kuitenkin päättymätön matka, monesti matka räntäsateessa. Tilanteet ovat vaihtelevia, samoin ihmisten mielipiteet ja mieltymykset. Yksi ratkaisu voi sopia yhteen tilanteeseen, toinen toiseen.

Yhteenvetona uuden luvun tarkastelusta voisi nousta esiin toivomus, että yksilön luovaa kykyä arvostetaan erityisesti asiantuntijayhteisöissä enemmän kuin hänen kykyään sopeutua. 